\title{
A New Role for Old Ligands: Discerning Chelators for Zinc Metalloproteinases
}

\author{
Faith E. Jacobsen, Jana A. Lewis, and Seth M. Cohen * \\ Dept. of Chemistry and Biochemistry, University of California, San Diego \\ La Jolla, CA 92093
}

\section{Supporting Information}

*Author to whom correspondence should be addressed. Telephone: (858) 822-5596.

FAX: (858) 822-5598. E-mail: scohen@ucsd.edu. 


\section{Experimental Section}

General. $\left[\left(\mathrm{Tp}^{\mathrm{Ph}, \mathrm{Me}}\right) \mathrm{ZnOH}\right]$ was synthesized as previously described (Puerta D.T.; Cohen S.M. Inorg. Chem. 2002, 41, 5075). Elemental analysis was performed at the NuMega Resonance Labs (San Diego, California). ${ }^{1} \mathrm{H} /{ }^{13} \mathrm{CNMR}$ spectra were recorded on a Varian FT-NMR spectrometer running at $400 \mathrm{MHz}$ at the Department of Chemistry and Biochemistry, University of California, San Diego. Infrared spectrum was collected on a Nicolet AVATAR 380 FT-IR instrument at the Department of Chemistry and Biochemistry, University of California, San Diego. Caution! Perchlorate salts of metal complexes with organic ligands are potentially explosive. Only small amounts of these materials should be prepared and they should be handled with great care.

$\left[\left(\mathbf{T p}^{\mathrm{Ph}, \mathrm{Me}}\right) \mathbf{Z n}(\mathbf{1})\right]$. In a $50 \mathrm{~mL}$ round-bottom flask, [(Tp $\left.\left.{ }^{\mathrm{Ph}, \mathrm{Me}}\right) \mathrm{ZnOH}\right](100 \mathrm{mg}, 0.176$ mmol) was added to $19 \mathrm{~mL}$ of $\mathrm{CH}_{2} \mathrm{Cl}_{2}$. To this solution was added 1.0 equiv of $\mathbf{1}$ (21.6 $\mathrm{mg}, 0.176 \mathrm{mmol}$ ) dissolved in $10 \mathrm{~mL}$ of methanol. The mixture was stirred at room temperature overnight under a nitrogen atmosphere. After stirring, the solution was evaporated to dryness on a rotary evaporator to give a white solid. The solid was dissolved in a minimum amount of benzene $(\sim 3 \mathrm{~mL})$, filtered to remove any insoluble material, and the filtrate was recrystallized by diffusion of the solution with pentane. Yield: $88 \%$. ${ }^{1} \mathrm{HNMR}\left(\mathrm{CDCl}_{3}, 400 \mathrm{MHz}, 25^{\circ} \mathrm{C}\right): \delta 2.59\left(\mathrm{~s}, 9 \mathrm{H}\right.$, pyrazole- $\left.\mathrm{CH}_{3}\right), 6.23(\mathrm{~s}$, $3 \mathrm{H}$, pyrazole-H), $7.34(\mathrm{~m}, 11 \mathrm{H}$, phenyl-H), 7.68 (d, 6H, phenyl-H), $7.85(\mathrm{~m}, 1 \mathrm{H}$, phenyl-H), $7.96\left(\mathrm{~m}, 1 \mathrm{H}\right.$, phenyl-H), $8.32\left(\mathrm{~m}, 1 \mathrm{H}\right.$, phenyl-H). ${ }^{13} \mathrm{CNMR}\left(\mathrm{CDCl}_{3}, 100\right.$ $\left.\mathrm{MHz}, 25{ }^{\circ} \mathrm{C}\right): \quad \delta 13.3,104.9,105.6,122.9,125.9,127.6,128.3,128.6,128.9,129.1$, 132.3, 145.6, 153.5. IR (film from $\mathrm{CH}_{2} \mathrm{Cl}_{2}$ ): $v 694,774,1059,1167,1344,1671,2539$ 
(B-H), 2945, $3059 \mathrm{~cm}^{-1}$. Anal. Calcd for $\mathrm{C}_{36} \mathrm{H}_{33} \mathrm{~N}_{7} \mathrm{O}_{2} \mathrm{BZn} \cdot 2 / 3 \mathrm{C}_{6} \mathrm{H}_{6}:$ C, 66.45; H, 5.02;

N, 13.56. Found: C, 66.22; H, 5.55; N, 13.32 .

X-Ray Crystallographic Analysis. Colorless blocks suitable for X-ray diffraction were grown from a solution of the complex in benzene diffused with pentane. A crystal was mounted on a quartz capillary by using Paratone oil and cooled in a nitrogen stream on the diffractometer. Data was collected on a Bruker AXS diffractometer equipped with area detectors. Peak integrations were performed with the Siemens SAINT software package. Absorption corrections were applied using the program SADABS. Space group determination was performed by the program XPREP. The structure was solved by direct methods and refined with the SHELXTL software package. All hydrogen atoms were fixed at calculated positions with isotropic thermal parameters and all nonhydrogen atoms were refined anisotropically. The hydrogen atom on the boron atom was found in the difference map and the position was refined. The compound co-crystallized with a one equivalent of benzene per complex.

Fluorescent MMP Assays. MMP-3 and MMP-1 activity were measured utilizing a 96-well microplate fluorescent assay kit purchased from Biomol Research Laboratories, following the procedure provided with the kit. Experiments were performed using a BioTek Flx 800 fluorescence plate reader and Nunic white 96-well plates. Inhibitors 1, 4, and 5 were dissolved in DMSO and further diluted (500×) into the assay buffer (MMP-3: 50 mM MES, $10 \mathrm{mM} \mathrm{CaCl2,} \mathrm{0.05 \%} \mathrm{Brij-35,} \mathrm{pH} \mathrm{6.0;} \mathrm{MMP-1:} 50$ mM HEPES, $10 \mathrm{mM}$ $\mathrm{CaCl} 2,0.05 \%$ Brij-35, $\mathrm{pH} 7.5$ ). Inhibitors $\mathbf{2}, \mathbf{3}, \mathbf{6}$, and 7 were dissolved directly into 
assay buffer. MMP-1 and MMP-3 were incubated with varying concentrations of inhibitors for $1 \mathrm{~h}$ at $37^{\circ} \mathrm{C}$, followed by addition of substrate to initiate the assay. The reactions were agitated by shaking for $1 \mathrm{sec}$ after each fluorescence measurement. Upon cleavage of the fluorescent substrate Mca-Pro-Leu-Gly-Leu-Dpa-Ala-Arg-NH2 (0.4 mM concentration in assay, $\mathrm{Mca}=$ (7-methoxycoumarin-4-yl)-acetyl, Dpa $=$ N-3-(2,4dinitrophenyl)-L- $\alpha$ - $\beta$-diaminopropionyl) at the Gly-Leu bond, Mca fluorescence (ëex = $335 \mathrm{~nm}$, ëem $=405 \mathrm{~nm}$ ) was measured at 60-second intervals for 20 minutes for MMP-3 and 60 minutes for MMP-1.

Recombinant Anthrax Lethal Factor Assays. Activities of Bacillus anthracis recombinant anthrax lethal factor (Calbiochem) were measured following literature procedures with some modifications (R.T. Cummings, S.P. Salowe, B.R. Cunningham, J. Wiltsie, Y.W. Park, L.M. Sonatore, D. Wisniewski, C.M. Douglas, J.D. Hermes, and E.M. Scolnick, Proc. Nat. Acad. Sci. USA, 2002, 99, 6603-6606). Experiments were performed using a Bio-Tek Flx 800 fluorescence plate reader and Nunc white 96-well plates. Inhibitors 1, 4, and 5 were dissolved in DMSO and further diluted $(500 \times)$ into the assay buffer (20 mM HEPES, $1.0 \mathrm{mM} \mathrm{CaCl}_{2}, 0.1 \mathrm{mg} / \mathrm{ml} \mathrm{BSA,} \mathrm{0.1 \%} \mathrm{Tween-20,} \mathrm{pH} \mathrm{7.0).}$ Inhibitors 2, 3, 6, and 7 were dissolved directly into assay buffer. LF (3 nM final concentration in assay) was incubated with varying concentrations of different inhibitors for $45 \mathrm{~min}$ at $25^{\circ} \mathrm{C}$, followed by addition of substrate to initiate the assay. Reactions were agitated by shaking for $1 \mathrm{sec}$ after each fluorescence measurement. Upon cleavage of the fluorescent substrate, (Cou)-N-Nle-Lys-Lys-Lys-Lys-Val-Leu-Pro-Ile-Gln-LeuAsn-Ala-Ala-Thr-Asp-Lys-(QSY-35)-Gly-Gly- $\mathrm{NH}_{2}(0.75 \mu \mathrm{M}$ in assay; $\mathrm{Cou}=7$-hydroxy- 
4-methyl-3-acetylcoumarinyl; $\quad$ QSY-35 = N-((4-((7-nitro-2,1,3-benzoxzdiazol-4yl)amino)phenyl) acetyl), at the Pro-Ile bond the Cou fluorescence was measured at 60second intervals for $20 \min \left(\lambda_{\mathrm{ex}}=380 \mathrm{~nm}, \lambda_{\mathrm{em}}=450 \mathrm{~nm}\right)$. Experiments were repeated in at least triplicate. $\mathrm{IC}_{50}$ values were calculated as the inhibitor concentration at which the enzyme is at $50 \%$ control activity (no inhibitor present).

Lipoxygenase Assay. Linoleic acid and type 1-B soybean lipoxygenase as a lyophilized power at $\geq 100,000 \mathrm{U} / \mathrm{mg}$ were purchased from Sigma-Aldrich. Taking into account the $60 \%$ stabilizers in the lyophilized powder a stock solution of $10,000 \mathrm{U} / \mathrm{mL}$ protein in $0.1 \mathrm{M}$ borate buffer $(\mathrm{pH} 9)$ was prepared. Soybean lipoxygenase (final concentration $250 \mathrm{U} / 1.5 \mathrm{~mL}$ reaction volume) was preincubated with chelator (diluted from 1 M DMSO stock; final concentration $100 \mu \mathrm{M}$ ) or respective dilutent for 3 hours. After preincubation the reaction was initiated by the addition of linoleic acid (diluted from 3.21 $\mathrm{M}$ ethanol stock solution; final concentration $667 \mu \mathrm{M}$ ). The rate of reaction was monitored by increase in absorbance at $234 \mathrm{~nm}$ over $20 \mathrm{~min}$. Percent activity was determined by dividing the slope of samples with inhibitors by the slope of control samples. Experiments were performed using a Perkin-Elmer Lambda 25 spectrophotometer. 
Table S1. $\mathrm{IC}_{50}$ values for ZBGs against MMP-1 measured by using a fluorescence-based assay. All values obtained from at least three independent experiments.

\begin{tabular}{|l|l|l|}
\hline ZBG & MMP-1 IC $\mathbf{5 0}(\mu \mathbf{M})$ & Potency v. AHA \\
\hline AHA & $41600( \pm 400)$ & n/a \\
\hline $\mathbf{1}$ & $2500( \pm 150)$ & 17 -fold \\
\hline $\mathbf{2}$ & $5688( \pm 79)$ & 7 -fold \\
\hline $\mathbf{3}$ & $13480( \pm 710)$ & 3 -fold \\
\hline $\mathbf{4}$ & $430( \pm 10)$ & 98 -fold \\
\hline $\mathbf{5}$ & $63( \pm 4)$ & 660 -fold \\
\hline $\mathbf{6}$ & $510( \pm 60)$ & 82 -fold \\
\hline $\mathbf{7}$ & $3490( \pm 120)$ & 12 -fold \\
\hline
\end{tabular}


Table S2. X-ray structure data for the complexes $\left[\left(\mathrm{Tp}^{\mathrm{Ph}, \mathrm{Me}}\right) \mathrm{Zn}(\mathbf{1})\right]$.

\begin{tabular}{|l|l|}
\hline & {$\left[\left(\mathrm{Tp}^{\mathrm{Ph}, \mathrm{Me}}\right) \mathrm{Zn}(\mathbf{1})\right]$} \\
\hline Empirical Formula & $\mathrm{C}_{42} \mathrm{H}_{38} \mathrm{BN}_{7} \mathrm{O}_{2} \mathrm{Zn}$ \\
\hline Crystal System & Orthorhombic \\
\hline Space Group & $P 2{ }_{1} 2_{1} 2_{1}$ \\
\hline Unit Cell dimensions & $a=8.8038(5) \AA$ \\
& $b=14.5333(7) \AA$ \\
\hline$R_{1}=\sum=29.4585(15) \AA$ \\
\hline Volume, $Z$ & $\alpha=\beta=\gamma=90^{\circ}$ \\
\hline Crystal size & $3769.2(3) \AA^{3}, 4$ \\
\hline Temperature $(\mathrm{K})$ & $0.25 \times 0.20 \times 0.10 \mathrm{~mm}_{c}^{3} \| / \sum\left|F_{o}\right|, R_{2}=\left\{\sum\left[w\left(F_{o}^{2}-F_{c}^{2}\right)^{2}\right] / \sum_{0}\left[w F_{o}^{4}\right]\right\}^{1 / 2}$ \\
\hline Reflections collected & $100(2)$ \\
\hline Independent reflections & $8382[R(\mathrm{int})=0.0214]$ \\
\hline Data/restraints/parameters & $8382 / 0 / 485$ \\
\hline Goodness-of-fit on $\mathrm{F}^{2}$ & 1.043 \\
\hline Final $R$ indices I $>2 \sigma(\mathrm{I})^{a}$ & $R 1=0.0288$ \\
\hline$R$ indices (all data ${ }^{a}$ & $R 1=0.0310$ \\
\hline
\end{tabular}



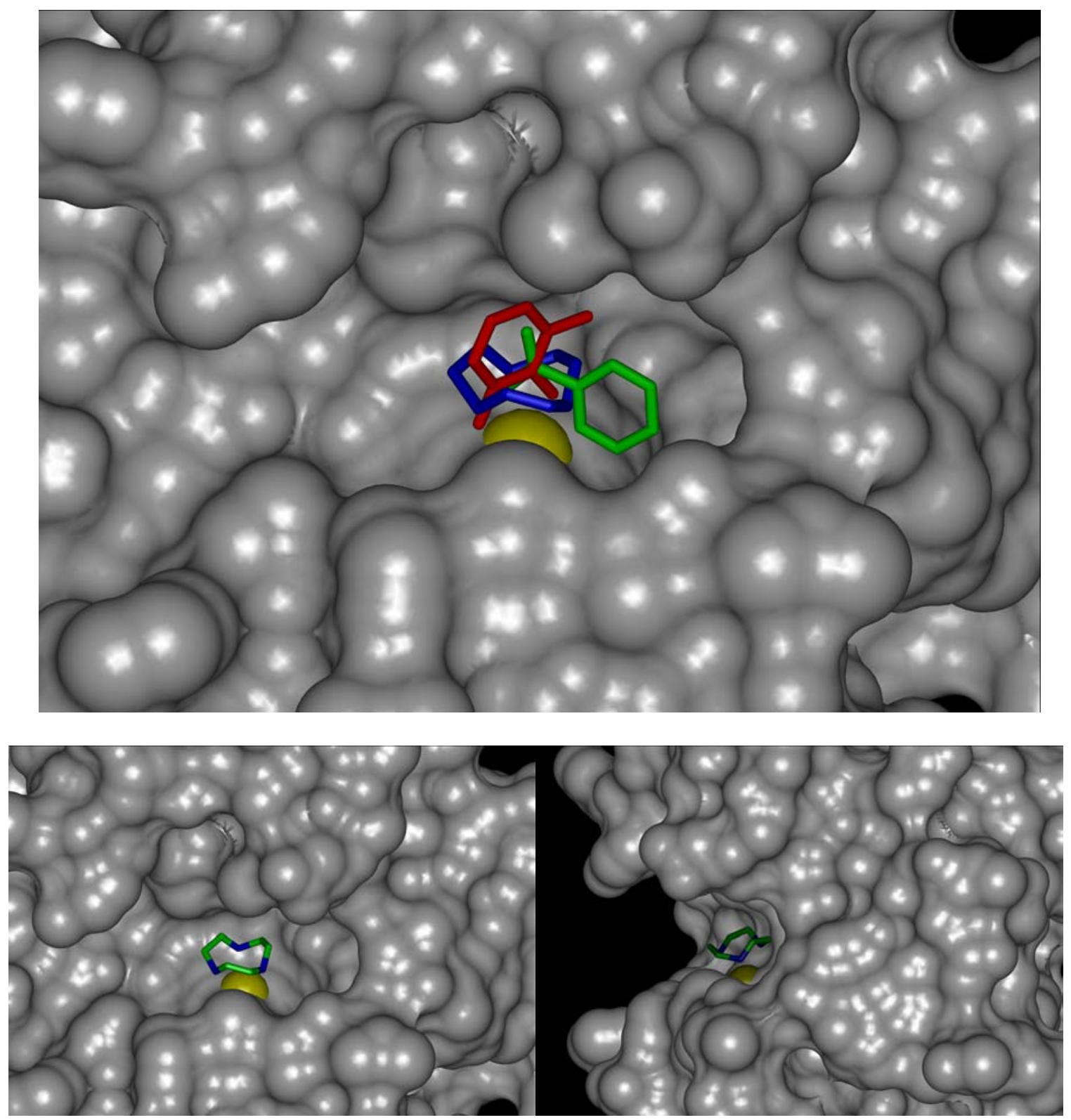

Figure 3. Top: Comparison of maltol (red), 1 (picolinic acid, green), and 5 (TACN, blue) superpositioned into the MMP-3 $(1 \mathrm{G} 4 \mathrm{~K})$ active site. Bottom: Two views of 5 (TACN) in the active site of MMP-3, showing that this macrocyclic ZBG is not too large to access the active site metal ion in this protein. The $\mathrm{Zn}^{2+}$ ions are shown as gold spheres. For the superposition of $\mathbf{5}$ the structure of the homoleptic complex $\left[\mathrm{Zn}(\mathbf{L})_{2}\right]^{2+}$ was utilized (Chaudhuri et al. Inorg. Chem. 1992, 31, 1457-1462). 